\title{
New Geometric Models for Calculation of Microalgal Biovolume
}

\author{
Bárbara Idino Konoplya* and Francisco Striquer Soares \\ ${ }^{1}$ Departamento de Biologia Animal e Vegetal; Centro de Ciências Biológicas; Universidade Estadual de Londrina; \\ 86051-990; Londrina - PR - Brasil
}

\begin{abstract}
Biovolume calculation of micro algae is commonly used for the assessment in relative abundance (as biomass or carbon) of coexistent algae that vary in shape and/or size. Periphyton samples were obtained within a more general program, in fishery tanks and streams situated in the upper basin region of Tibagi River, nearby Londrina, Paraná state, south of Brazil. The present work proposes new algorithms for the determination of algal species volume. Results showed that Gyrosigma scalproides (Rabenhorst) Cleve 1894 and Tetraedron gracile (Reinsch) Hansgirg 1889 were exceptions inside their genus and the present new formula for biovolume and area gives more adequate results. In addition, new formulas applied for Phacus longicauda (Ehrenberg) Dujardin 1841 and Kirchneriella lunaris (Kirchner) Möbius 1894 also showed much more accurate results than in the previous works. The difference in the calculations of biovolume between the present method and others was not small and could not be neglected.
\end{abstract}

Key words: biovolume, geometric models, biomass, micro algae

\section{INTRODUCTION}

Planktonic algal organisms are important primary producers of aquatic systems, fixing carbon in their biomass by photosynthetic processes and this way, they become an important component of food web basis (Levinton, 2001; Raven et al., 2001; Blinn and Bailey, 2001; Dubinsky et al., 1998). Therefore, the more precise will be the knowledge about available "standing stock" of these organisms in the water mass, the more secure will be the interpretation of the ecological processes in these environments (Menden-Deuer and Lessard, 2000; Smayda, 1978).

The methods for evaluating the planktonic algal biomass may be direct, such as the cell count, biovolume, estimation of chlorophyll-a, or other organic component, or indirect, such as the estimation of carbon concentration, nitrogen, from biovolume (Hillebrand et al., 1999; Menden-Deuer and Lessard, 2000; Smayda, 1978). In addition, evaluations can be done with the methods using computer, which shortens the time spent on the analysis, or which may increase the precision in results (Montagnes et al., 1994; Hillebrand et al., 1999). But, independent of the selected method, its validity and precision depends on the used algorithm. In the case of biovolume measurements, the more the algorithm takes into account variations in algal cell shapes, the more accurate it will be.

The present work proposes new algorithms for the determination of algal species volume of Phacus longicauda (Ehrenberg) Dujardin 1841,

*Author for correspondence: barbcast_1@yahoo.com.br 
Gyrosigma scalproides (Rabenhorst) Cleve 1894, Kirchneriella lunaris (Kirchner) Möbius 1894 and Tetraedron gracile (Reinsch) Hansgirg 1889.

\section{MATERIAL AND METHODS}

The new biovolume formula were applied to the organisms which had been taken within a more general program, where periphyton samples were collected with multi-habitat method described by Porter et al. (1993), monthly from May 2001 until April 2002, except October.

These samples were obtained in fishery tanks and streams situated in the upper basin region of Tibagi River. The sampling stations were located in Londrina and other cities nearby, in Paraná state, south of Brazil. In the region of Londrina, three fishery tanks for sampling were chosen, where two of them already have suffered the effects of soil eutrofication. In addition, more eight stations in Cambé River and tributaries were sampled from the spring until not reaching Igapó Lake.

The samples for each station were put in the bottles and were fixed with $50 \%$ of Transeau solution (Bicudo and Bicudo, 1970) and phytoplankton samples were processed using a microscope Zeiss Axioscop.

Biovolume and area formula were calculated from the median of measured linear dimensions, not as a mean (or median) of a set of individually calculated biovolumes and the application of these shapes at the genus or species level was applied to individual cells as performed by Hillebrand et al. (1999). For each phytoplankton assemblage, 25 randomly selected cells of each species were measured (Smayda, 1978).

\section{RESULTS AND DISCUSSION}

One practical way of calculating the biovolume is based on geometric shapes, according to the measured linear dimensions obtained by light microscope (Steinman et al., 1991, Snoeijs, 1994, Sommer, 1994, 1995, Hillebrand and Sommer, 1997), once it is considered convenient during routine analysis (Kononen et al., 1984).

Despite Utermöhl's (1931) sedimentation method is the most recommended for measurements for calculation of biovolume; it is not practical when using X 1000 magnification. Therefore, the aim in this work was just to verify the accuracy of different proposed formula for the organisms; using non-inverted microscope.

Starting from earlier works of Edler (1979), Rott (1981), Hillebrand et al. (1999) and Sun and Liu (2003), a better geometrical approximation was developed for some species of phytoplankton, such as Phacus longicauda (Ehrenberg) Dujardin 1841, Gyrosigma scalproides (Rabenhorst) Cleve 1894, Kirchneriella lunaris (Kirchner) Möbius 1894, and Tetraedron gracile (Reinsch) Hansgirg 1889. Phytoplankton species according to the two criteria were on focus: first, species commonly found in fishery tanks and streams of the upper basin region of Tibagi River were chosen, and second, those species which have a rather complicated geometrical form and could not be well-approximated within approach used in Edler (1979), Rott (1981), Hillebrand et al. (1999) and Sun and Liu (2003) were of interest.

The species of phytoplankton, in most cases, could be represented as a number of some regular canonical geometric figures (such as the prism on elliptic base, the prolate spheroid, the parallelogram, etc.). Yet, for instance for Phacus longicauda such a simple representation is impossible, if one takes into consideration the prolongation of cytoplasm of Phacus longicauda. For the latter case geometrical fit for the average form of the boundary of the species was developed and found the bio-volume using the analytical interpretation of the volume as a definite integral over the space of the species.

The formula in some previous papers are based on the canonical geometric figures, which does not take into consideration the deviations from standard forms, like ellipse, triangle, rectangle and others, on the plane, and corresponding threedimensional cylindrical bodies. Therefore, the algorithm of the previous analytical approaches was improved, especially from Hillebrand, et al. (1999), by introducing better approximation for some forms of micro algae.

\section{Phacus longicauda}

Phacus longicauda (Fig. 1) is an organism which can be approximated by a cylindrical body with base in the form of ellipse with a prolongation of cytoplasm. In Figure 2, where the length is $\mathrm{A}=10$, and the length of the prolongation of cytoplasm is $\mathrm{B}=17$, in some units, one can see the half of the prolongation of cytoplasm approximated by a quadratic function. Note that for derivation of the 
formula only the ration $\mathrm{A} / \mathrm{b}$ would be needed, so that the scale in Figure 2 could be any. In 2dimensional Cartesian coordinates $(\mathrm{x} ; \mathrm{y})$, the halfboundary of the prolongation of cytoplasm could be represented by the following function:

$$
\mathrm{y}(\mathrm{x}) \approx 0.68 \mathrm{x}^{2}
$$

The integral is elementary:

$$
\int_{0}^{\mathrm{A} / 2} 0.68 \mathrm{x}^{2} \mathrm{dx}=0.028333 \mathrm{~A}^{3}
$$

The biovolume $\mathrm{V}$ of this alga is the area of the base $S_{\text {base }}$ times the depth $\mathrm{H}$.

$\mathrm{S}_{\text {base }}=2 \int_{0}^{\mathrm{A} / 2} \mathrm{y}(\mathrm{x}) \mathrm{dx}+(\pi / 4) \mathrm{CD}$,

$$
\mathrm{V}=\left(2 \int_{0}^{\mathrm{A} / 2} \mathrm{y}(\mathrm{x}) \mathrm{dx}+(\pi / 4) \mathrm{C} D\right) \mathrm{H} \text {, }
$$

The area of the base $S_{\text {area }}$ is calculated as an integral:

$\mathrm{S}_{\text {area }}=2\left(2 \int_{0}^{\mathrm{A} / 2} \mathrm{y}(\mathrm{x}) \mathrm{dx}+(\pi / 4) \mathrm{C} \mathrm{D}\right)$.

where the function $\mathrm{y}(\mathrm{x})$ is given by $\mathrm{Eq}(1)$.

Thus, the coefficient 0.68 in (1) is determined by the ratio $\mathrm{A} / \mathrm{B}$.

Now, an alternative model for function $\mathrm{y}(\mathrm{x})$ could be suggested, which gives much better accuracy than quadratic function used.

The fit of the following form:

$\mathrm{y}(\mathrm{x})=\mathrm{A}_{0}+\mathrm{A}_{1} \mathrm{x}^{1 / 2}+\mathrm{A}_{2} \mathrm{x}^{1}+\mathrm{A}_{3} \mathrm{x}^{3 / 2}+\mathrm{A}_{4} \mathrm{x}^{2}+\mathrm{A}_{5}$

$\mathrm{x}^{5 / 2}+\mathrm{A}_{6} \mathrm{x}^{3}$

proved to be very good for representing the form of the prolongation of cytoplasm of Phacus longicauda. The corresponding integral is

$$
\begin{aligned}
& \mathrm{y}(\mathrm{x})=\frac{\mathrm{A} \mathrm{A}_{0}}{2}+\frac{\mathrm{A}^{3 / 2} \mathrm{~A}_{1}}{3 \sqrt{2}}+\frac{\mathrm{A}^{2} \mathrm{~A}_{2}}{8}+\frac{\mathrm{A}^{5 / 2} \mathrm{~A}_{3}}{10 \sqrt{2}}+\frac{\mathrm{A}^{3} \mathrm{~A}_{4}}{24} \\
& +\frac{\mathrm{A}^{7 / 2} \mathrm{~A}_{5}}{28 \sqrt{2}}+\frac{\mathrm{A}^{4} \mathrm{~A}_{6}}{64}
\end{aligned}
$$

The coefficients $A_{i}$ are determined by the ratio $\mathrm{A} / \mathrm{B}$. Note that formulas (2) and (6) do not show explicit dependence on $\mathrm{B}$, because this dependence is implicit in the numerical values of the coefficients. For the average value of $\mathrm{A}$ and $\mathrm{B}$ measured, these coefficients are:

$\mathrm{A}_{0}=-0.000688450930597$,

$\mathrm{A}_{1}=-0.750636834976341$,

$\mathrm{A}_{2}=6.1125715638814070$,

$\mathrm{A}_{3}=-15.73399989778222$,

$\mathrm{A}_{4}=18.999517106351234$,

$\mathrm{A}_{5}=-10.29427433495737$,

$\mathrm{A}_{6}=2.116087928411902$.

Note, that for another values of $\mathrm{A}$ and $\mathrm{B}$, these coefficients will be different. In order to find them, one needs to repeat the fit procedure for the shape of $P$. longicauda. The two choices for functions $\mathrm{y}(\mathrm{x})$ (quadratic and as a truncated series expansion) are plotted in Figure 2. The contributions to the total biovolume of $P$. longicauda, according to the two above choices for $y(x)$ differed only by $1.2 \%$. Therefore, one could prefer the simpler quadratic function (1).

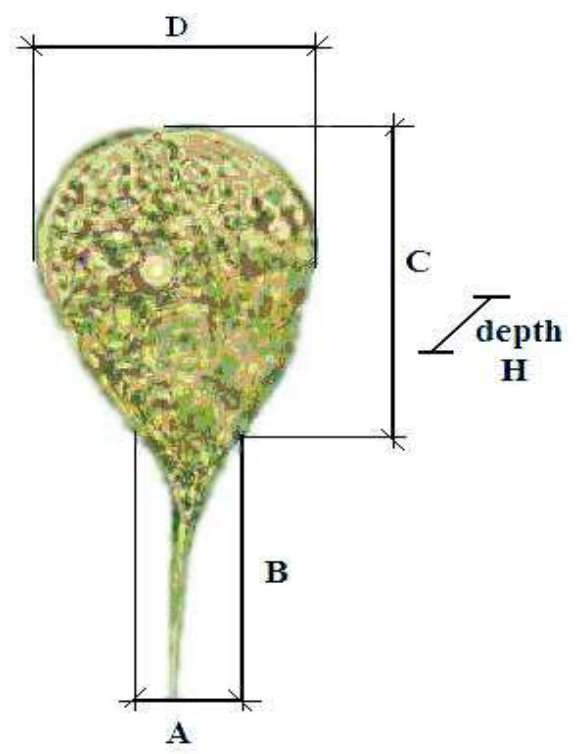

Figure 1 - Measurements used for calculation of biovolume in Phacus longicauda. 


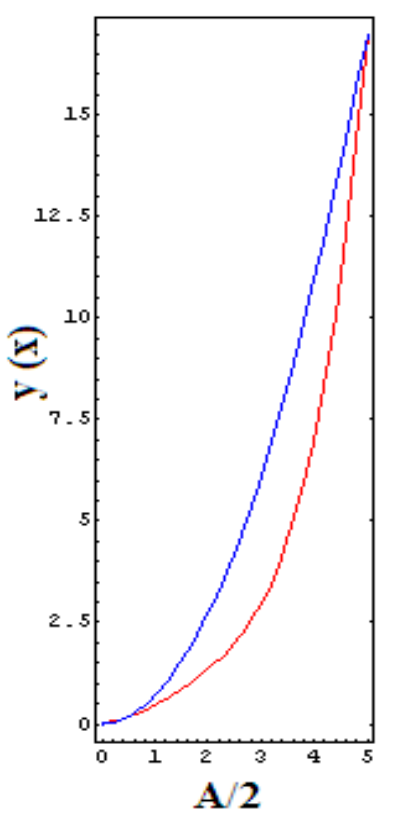

Figure 2 - Half-boundary of the prolongation of cytoplasm of Phacus longicauda in the (x; y) coordinates. Blue line represents quadratic function (1) and red line represents series expansion. (1a).

The proposed shape of $P$. longicauda was compared with previous shapes proposed by Rott (1981) who considered that Phacus sp as halfellipsoid plus half-cone, and with those proposed by Hillebrand et al. (1999) who considered this algae as an elliptic prism. For all cases, the depth of the organism here was considered as $10 \mu \mathrm{m}$, based on the measurements of depth of apical section in girdle view of cells of $P$. torta (Lemmermann) Skvortzow 1928. If to consider the height of two cell membranes plus cytoplasm content inside the cell, even if it is described as leaf-flat (Leedale, 1967) genus, this estimation made from $P$. torta can provide good idea of depth for $P$. longicauda cell. If not, at least a good comparison of accuracy among different formula. Results obtained by Rott (1981) (see Fig. 7) showed one value $61.61 \%$ smaller than the one obtained here (considering the present results as $100 \%$ ) and Hillebrand et al. (1999) showed a value $27.889 \%$ smaller than that obtained here.

\section{Gyrosigma scalproides}

The biovolume of this pennate diatom could be represented by a sigmoid prism. Good approximation to the volume of this sigmoid prism (Fig. 3) could be a volume of rectangular box $A B H$ subtracted the volume $A C H$ of the two prisms with triangular bases. Thus, the biovolume $\mathrm{V}$ is
$\mathrm{V}=\mathrm{HA}(\mathrm{B}-\mathrm{C})$.

$$
\mathrm{S}_{\text {area }}=2\left[(\mathrm{~A}+\mathrm{H})(\mathrm{B}-\mathrm{C})+\sqrt{\left.\mathrm{A}^{2}+\mathrm{C}^{2}\right] \mathrm{H}}\right.
$$

For G. scalproides, the present formula was compared with that of Hillebrand et al. (1999) which considered Gyrosigma sp as an "equilateral parallelogram", without subtracting volume $A C H$, and Edler (1979) that considered this genus as ellipsoid. In the present work, the depth was considered as equal to $=\mathrm{A}$ due to impossibility of its visualization in the samples. It happened because sometimes, depending on the position that the organism took in front the camera, it became difficult, if not practically impossible, to measure the third dimension. For instance, measuring of the third dimension of radially asymmetric cells is often a problem in microscopy (Hillebrand et al., 1999). Another problem is that all leaf-flat forms and dorsiventral forms practically cannot be measured directly, due to preferential position they take almost always in the sedimentation camera. Many authors have suggested different solutions, such as calibrating fine focus of the microscope or estimating the length-width-thickness relations of individuals in transverse position or measuring and observing the living material (Rott, 1981). In the case of nanophytoplankton, Verity et al. (1992) found that measuring of the third dimension could be omitted. An assumption of a prolate spheroid 
form, in which depth equals the width, would results in little difference from measuring all the three dimensions. But for larger cells, such as pennate diatoms, it was not true, as reported by Hillebrand et al. (1999).

Another option is the method proposed by McCartney (1988, cited from McCartney and Loper, 1989), that involves the adjustment knob of a light microscope to which a potentiometer is added to measure the distance from the bottom to the top focus of the cells.

In summary, measuring of the third dimension of some phytoplankton species becomes rather difficult, if the sampler does not have access to the living material or some apparatus to adjust in microscope. Then, a good option would still be the estimation of length-width-thickness relations of individuals in transverse position as proposed by Rott (1981).

Estimations obtained by the present formula showed a value $33.05 \%$ bigger than the one obtained by Hillebrand et al. (1999), and the results were $4.91 \%$ smaller than those showed by Edler (1979) (Fig. 7). This showed that $G$. scalproides was one exception inside its genus and could not be considered as an equilateral parallelogram. The difference was big in such a way that if one considered this species as one ellipsoid, would reach the values much more accurate than the ones proposed previously for this genus.

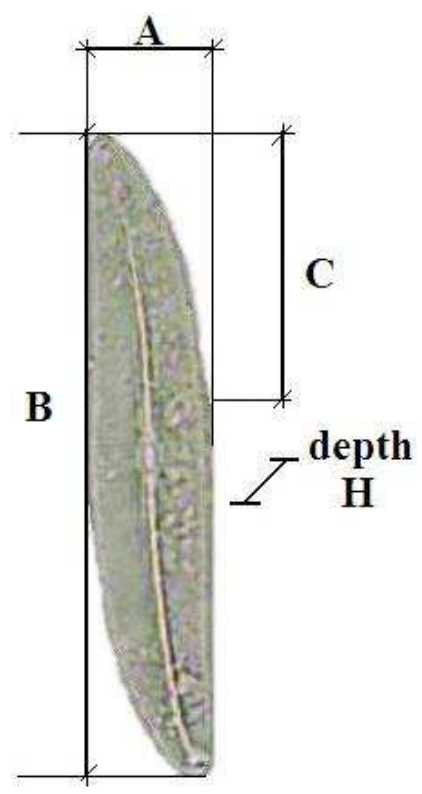

Figure 3 - Measurements used for calculation of biovolume in Gyrosigma scalproides, considering depth as $\mathrm{H}$.

\section{Kirchneriella lunaris}

Hillebrand et al. (1999) reported the form of $K$. lunaris ellipsoid with two cones while Edler (1979) approximated this genus as rotational ellipsoid. Better approximation should be an ellipsoid with a hollow of ellipsoid form (Fig. 4). The formula for biovolume and area is

$$
\begin{aligned}
& \mathrm{V}=(\pi / 6)\left(\mathrm{H} A \mathrm{~B}-\mathrm{H}^{\prime} \mathrm{A}^{\prime} \mathrm{B}^{\prime}\right), \\
& \mathrm{S}_{\text {area }} \approx \mathrm{S}(\mathrm{B}, \mathrm{H}, \mathrm{A})-\mathrm{S}\left(\mathrm{B}^{\prime}, \mathrm{H}^{\prime}, \mathrm{A}^{\prime}\right), \\
& \mathrm{S}(\mathrm{B}, \mathrm{H}, \mathrm{A}) \approx(\pi / 4)(\mathrm{A}+\mathrm{H})\{(\mathrm{A}+\mathrm{H}) / 2+ \\
& \left.\left(2 \mathrm{~B}^{2}\right) / \sqrt{4 \mathrm{~B}^{2}-(\mathrm{A}+\mathrm{H})^{2}} \sin ^{-1}\left[\sqrt{4 \mathrm{~B}^{2}-(\mathrm{A}+\mathrm{H})^{2}}\right] / 2 \mathrm{~B}\right\},
\end{aligned}
$$

$$
\begin{aligned}
& \mathrm{S}\left(\mathrm{B}^{\prime}, \mathrm{H}^{\prime}, \mathrm{A}^{\prime}\right) \approx(\pi / 4)\left(\mathrm{A}^{\prime}+\mathrm{H}^{\prime}\right)\left\{\left(\mathrm{A}^{\prime}+\mathrm{H}^{\prime}\right) / 2+\right. \\
& \left(2 \mathrm{~B}^{\prime}\right) / \sqrt{4 \mathrm{~B}^{\prime 2}-\left(\mathrm{A}^{\prime}+\mathrm{H}^{\prime}\right)} \\
& \left.\left.\sin ^{-1}\left[\sqrt{4 \mathrm{~B}^{\prime 2}-\left(\mathrm{A}^{\prime}+\mathrm{H}^{\prime}\right.}\right)^{2}\right] / 2 \mathrm{~B}^{\prime}\right\}
\end{aligned}
$$

The present formula for $K$. lunaris gave a value of biovolume which was $17.35 \%$ less than that obtained by formula of Hillebrand et al. (1999), and $10.95 \%$ less than that of Edler (1979) (Fig. 7a and 7b). It was mainly because Edler (1979) did not discard the empty area inside the cell, while Hillebrand et al. (1999) considered the apical part of the cell as two cones. 

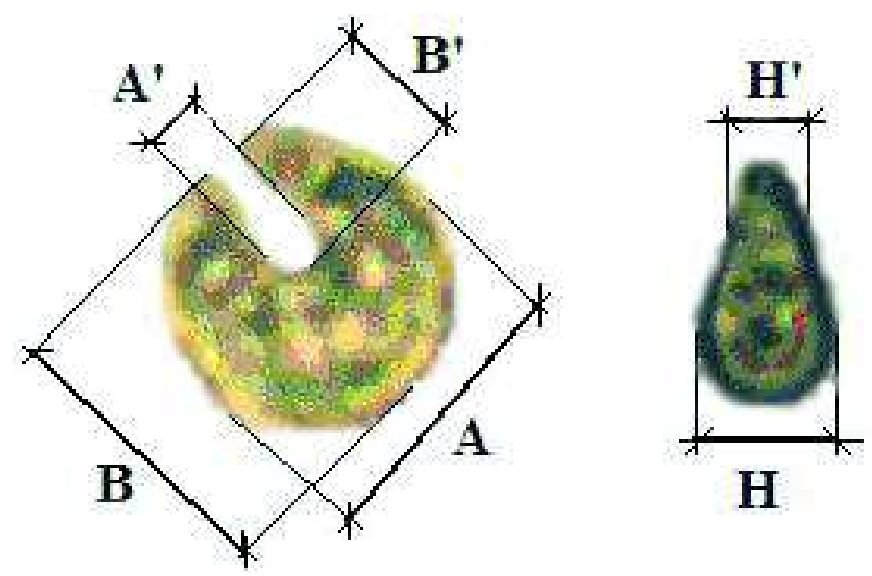

Figure 4 - Measurements used for calculation of biovolume of Kirchneriella lunaris.

\section{Tetraedron gracile}

The biovolume of $T$. gracile consisted of one central cube with sides $\mathrm{A}$; four trapezoids with sides $\mathrm{A} ; \mathrm{B}$, and depth $\left(\mathrm{A}+\mathrm{A}^{\prime}\right) / 2$; eight rectangles with sides $A^{\prime} ; B^{\prime}$; sixteen rectangles with sides A'; B', both rectangles with depth equal to A'; and two pyramids with base $\mathrm{A}$ and height $\mathrm{A} / 2$ (Fig. 5 and 6). Therefore, the biovolume and area are

$$
\begin{aligned}
& 8\left(A^{\prime 2} B\right)+16\left(A^{\prime \prime} B^{\prime \prime} A^{\prime}\right)+A^{3}+\frac{A^{3}}{3} \\
& S_{\text {area }}=8\left[\frac{A+A^{\prime}}{2} \sqrt{B^{2}-\frac{\left(A-A^{\prime}\right)^{2}}{4}}\right]+ \\
& 8(A B)+32\left(A^{\prime} B^{\prime}\right)+32\left(A^{\prime \prime} B^{\prime \prime}\right)+ \\
& 32\left(A^{\prime} B^{\prime \prime}\right)+16\left(A^{\prime \prime} A^{\prime}\right)+2 A^{2} \sqrt{ } 2 .
\end{aligned}
$$

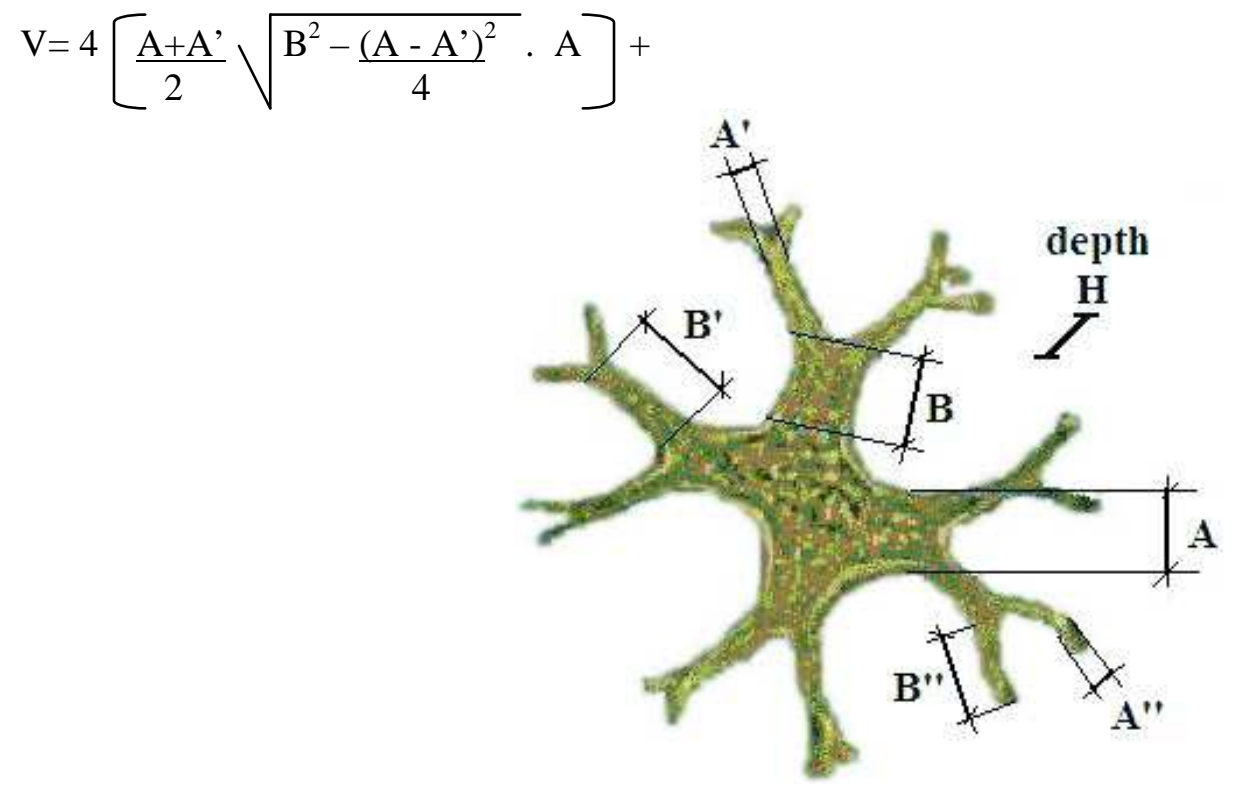

Figure 5 - Measurements used for calculation of biovolume of Tetraedron gracile.

The species $T$. gracile has a preferential position in laminula which makes difficult the visualization of its third dimension. This algae concentrates a bigger depth in the central area of the cell and diminishes this depth radially in direction to the periphery. After some efforts, one organism was found in such position that allowed making the measurements and estimations of the third dimension. This way, it would be possible to estimate the depth of each cell, even when this 
depth could not be distinguished. Therefore, based on the calculations, it was estimated that the central area had a depth twice bigger than the width of trapezoid $(\mathrm{AB})$. This depth diminished gradually until the point in which it coincided with the width of the rectangles (A'B') and continued this way in further ramifications. The results obtained by the present formula showed a value which was $88.37 \%$ smaller than the one obtained by Hillebrand et al. (1999) and Sun and Liu (2003), since both considered the genus Tetraedron sp as a box (Fig. 7). That could be the reason why in this genus, not only $T$. trigonum was an exception, as described Hillebrand et al. (1999), but also $T$. gracile was. In fact, there are other species of the genus Tetraedron that should be included as exceptions such as $T$. limneticum Borge and T. caudatum (Corda, 1839) Hansgirg, 1888. In the case of $T$. gracile, the present formula (13) for this species gave 8.6 times smaller value for biovolume, which meant that the previous formula of Hillebrand (1999) and Sun and Liu (2003) were simply inadequate.

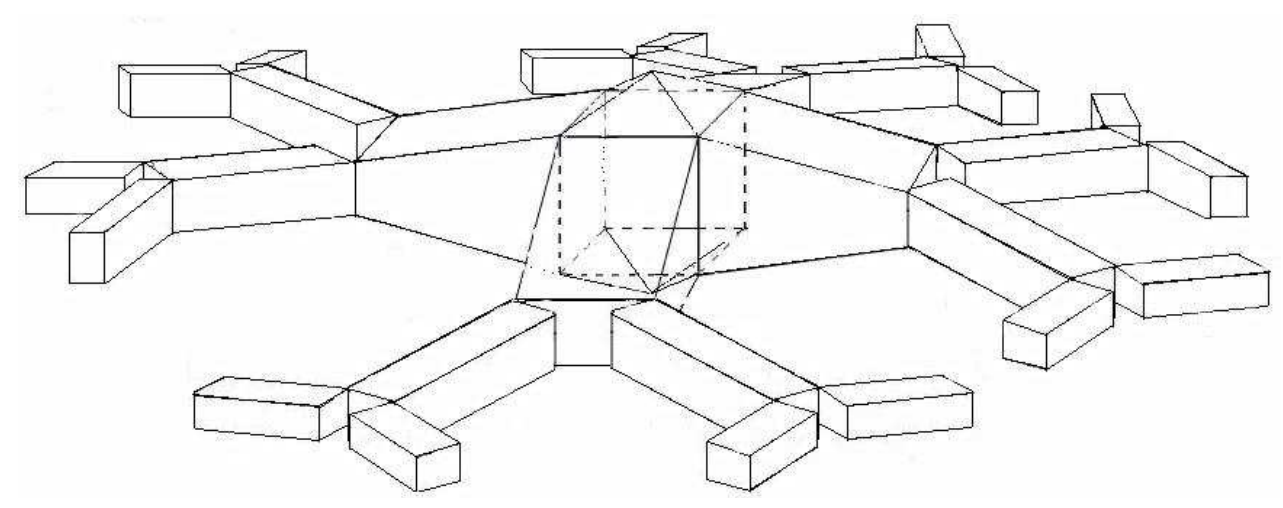

Figure 6 - Schematic drawing of Tetraedron gracile.

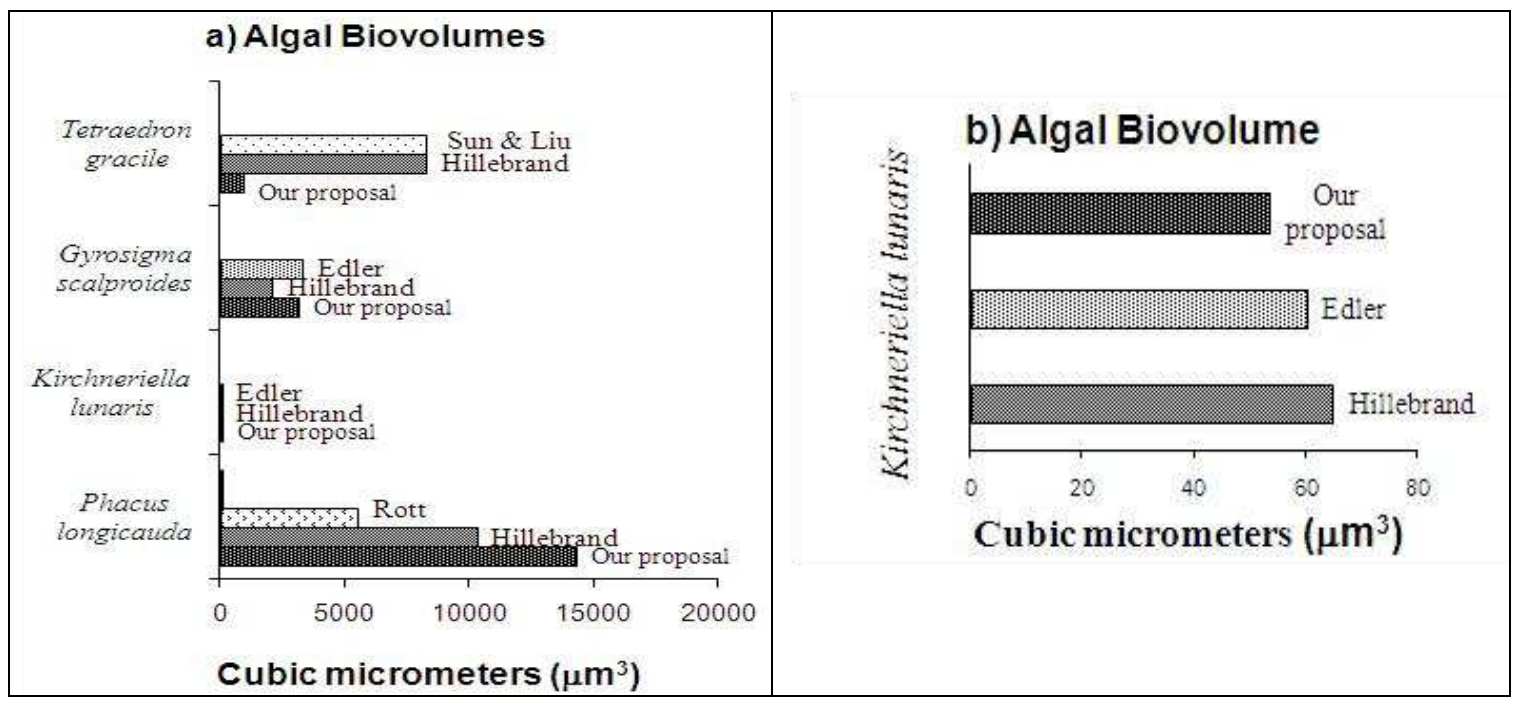

Figure 7 - a) Comparison of biovolume among methods for different species of micro algae; b) Comparison of biovolume among methods for Kirchneriella lunaris in a different scale.

\section{CONCLUSIONS}

Comparison of the biovolume formula as proposed in this work for some species with the formula of Edler (1979), Rott (1981), Hillebrand et al. (1999) and Sun and Liu (2003) showed considerable difference, which should not be neglected. This could improve the proposal for standardization made by Hillebrand et al. (1999) and suggested more accurate formula for biovolume. 
The present work showed that G. scalproides and $T$. gracile were exceptions in their genus, and the new formula for biovolume, as more adequate, should be used instead of previous ones. In the genus Tetraedron, not only $T$. trigonum was an exception, as described by Hillebrand et al. (1999), but also $T$. gracile. In addition, the new formula for biovolume of $P$. longicauda and $K$. lunaris also gave much more accurate results than the formula proposed in previous works.

\section{ACKNOWLEDGEMENTS}

This work was supported by the agreement UEL/CONFEPAR/FAUEL and by the scientific initiation support provided by UEL (Universidade Estadual de Londrina).

\section{REFERENCES}

Bicudo C. E. M. and Bicudo, R. M. T. (1970), Algas de águas continentais brasileiras. Fundação Brasileira. São Paulo - SP, 228p.

Blinn D. W. and Bailey, P. C. E. (2001). Land-use influence on stream water quality and diatom communities in Victoria, Australia: a response to secondary salinization. Hydrobiologia, 466, 231-244.

Dubinsky Z., Feitelson, J. and Mauzerall, D. C. (1998), Listening to Phytoplankton: Measuring Biomass and Photosynthesis by Photoacoustics. J Phycol, 34, 888892.

Edler L. (1979), Recommendations for marine biological studies in the Baltic Sea - phytoplankton and chlorophyll. Baltic Marine Biol, 5, 1-39.

Hillebrand H. and Sommer, U. (1997), Response of epilithic microphytobenthos of the Western Baltic Sea to in situ experiments with nutrient enrichment. Marine Ecol Progr Ser, 160, 35-46.

Hillebrand H., Dürselen, C. D., Kirschtel, D., Pollingher, U. and Zohary, T. (1999), Biovolume calculation for pelagic and benthic microalgae. $J$ Phycol, 35, 403-424.

Kononen K., Forsskähl, M., Huttunen, M., Sandell, M. and Viljamaa, H. (1984), Practical problems encountered in phytoplankton cell volume using the BMB recommendation in the Gulf of Finland. Limnologica, 15, 605-614.

Leedale G. F. (1967), Electronic and Utermöhl comparative techniques in quantitative analysis of freshwater particulates. Hydrobiologia, 57, 225-239.

Levinton J. (2001), Marine biology: function, biodiversity, ecology. Oxford University Press, Oxford, $515 \mathrm{pp}$.
Mc Cartney K. and Loper, D. E. (1989), Optimized skeletal morphologies of silicoflagellate genera Dictyocha and Distephanus. Paleobiology, 15, 283298.

Menden-Deuer S. and Lessard, E. J. (2000), Carbon to volume relationships for dinoflagellates, diatoms, and other protists plankton. Limnol Oceanogr, 45, 569579.

Montagnes D. J. S., Berges J. A., Harrison P. J. and Taylor F. J. R. (1994), Estimating carbon, nitrogen, protein and chlorophyll a from volume in marine phytoplankton. Limnol Oceanogr, 39, 1044-1060.

Porter S. D., Cuffney, T. F., Gurtz, M. E. and Meador, M. R. (1993), Methods for Collecting Algal Samples as Part of the National Water-Quality Assessment Program. U. S. Geological Survey, Report 93-409. Raleigh, North Carolina, USA. <http: Iwater.usgs.gov/nawqa/protocols/OFR-93409/alg1.html.>

Raven P. H., Evert, R. F. and Eichhorn, S. E. (2001), Biologia Vegetal. 6a. Ed. Guanabara Koogan, Rio de Janeiro. 906 pp.

Rott E. (1981), Some results from phytoplankton couting intercalibrations. Schweiz Z Hydrol, 43, 1.

Smayda T. J. (1978), What to count. In- Phytoplankton Manual, ed. A. Sournia. Monographs on oceanographic methodology 6. UNESCO, Paris, 165166.

Snoeijs P. (1994), Distribution of epiphytic diatom species composition, diversity and biomass on different macroalgal hosts along seasonal and salinity gradients in the Baltic Sea. Diatom Res, 9, 189-211.

Sommer U. (1994), Are marine diatoms favoured by high Si:N ratios? Marine Ecol Progr Ser, 115, 309315.

Sommer U. (1995), An experimental test of the intermediate disturbance hypothesis using cultures of marine phytoplankton. Limnol Oceanogr, 40, 12711277.

Steinman A. D., Mulholland, P. J. and Kirschtel, D. B. (1991), Interactive effects of nutrient reduction and herbivory on biomass, taxonomic structure, and $\mathrm{P}$ uptake in lotic periphyton communities. Can J Fish Aquat Sci, 48, 1951-1959.

Sun J. and Liu, D. (2003), Geometric models for calculating cell biovolume and surface area for phytoplankton. J Plankton Res, 25, 1331-1346.

Utermöhl H. (1931), Neue Wege in der quantitaven Erfassung des Planktons. Verh Int Ver Theor Angew Limnol, 5, 567-597.

Verity P. G., Robertson, C. Y., Tronzo, C. R., Andrews, M. G., Nelson, J. R. and Sieracki, M. E. (1992), Relationships between cell volume and the carbon and nitrogen content of marine photosynthetic nanoplankton. $J$ Phycol, 27, 351-360.

Received: March 31, 2009 Revised: August 06, 2010; Accepted: February 02, 2011. 